Saudi Journal of Medical and Pharmaceutical Sciences

Abbreviated Key Title: Saudi J Med Pharm Sci ISSN 2413-4929 (Print) |ISSN 2413-4910 (Online) Scholars Middle East Publishers, Dubai, United Arab Emirates Journal homepage: https://saudijournals.com/sjmps

\title{
"Non-Alcoholic Fatty Liver Disease and Metabolic Syndrome In Type 2 Diabetes Mellitus Patients in Rajshahi Medical College Hospital, Rajshahi, Bangladesh"
}

Ahmed Masiha Jamil ${ }^{1 *}$, Rahnuma Shirin², Azizul Hoque ${ }^{3}$, Khalilur Rahman ${ }^{4}$, Mohammad Mahbubur Rahman Khan ${ }^{5}$, Sk. Md. Afzal Uddin ${ }^{6}$

${ }^{1}$ Assistant Professor (Medicine), Rajshahi Medical College, Rajshahi, Bangladesh

${ }^{2}$ Medical Officer, Upazilla Health Complex, Mohonpur, Rajshahi, Bangladesh

${ }^{3}$ Associate Professor (Ex), Medicine, Rajshahi Medical College, Rajshahi, Bangladesh

${ }^{4,5}$ Professor (Medicine) Rajshahi Medical College, Rajshahi, Bangladesh

${ }^{6}$ Assistant Professor (Medicine), Rajshahi Medical College, Rajshahi, Bangladesh

DOI: $10.36348 /$ simps.2020.v06i02.008

| Received: 03.02.2020 | Accepted: 15.02.2020 | Published: 20.02.2020

*Corresponding author: Ahmed Masiha Jamil

\section{Abstract}

Introduction: Non-alcoholic fatty liver disease (NAFLD) has become a public health problem worldwide due to rising incidence of obesity and Type 2 diabetes mellitus. NAFLD is a common liver disorder that is strongly associated with insulin resistance and Type 2 diabetes mellitus. As a result of epidemic increase in hypertension, obesity, hypertriglyceridemia along with diabetes mellitus, prevalence of NAFLD and metabolic syndrome have increased globally. Objective: The aim of this study was designed to determine the proportion of NAFLD and metabolic syndrome in T2DM patients. Methodology: This was a cross sectional descriptive study conducted in medicine department, Rajshahi medical college, Rajshahi among ninety one T2DM patients. Abdominal ultrasonography for NAFLD detection and grading as well as measurement of blood pressue, BMI, waist circumference, HbA1c, lipid profile, liver function tests were done. All data were analysed by SPSS 16 and p value $<0.05$ was assumed as statistically significant in this study. Results: Out of ninety one DM patients $2 / 3^{\text {rd }}(67 \%)$ were male and remaining $1 / 3^{\text {rd }}(33 \%)$ were female. Mean age of them was $51.43 \pm 6.24$ years. Among study population $80.2 \%$ were obese, 31.8 were hypertensive and $72.5 \%$ had hypertriglyceridemia. Proportion of NAFLD and metabolic syndrome in T2DM patients was $60.4 \%$ and $61.5 \%$ respectively. $52.7 \%$ had mild whereas $47.3 \%$ had moderate fatty change in liver. Female had proportionately higher NAFLD than male. It was also observed that NAFLD was proportionately increased in higher age group but both age and gender were statistically insignificant $(\mathrm{p}>0.05)$. Long standing and uncontrolled DM was significantly associated with higher proportion and severe form of NAFLD respectively $(\mathrm{p}<0.05)$. Hypertension was not significantly associated with frequency and severity of NAFLD ( $>0.05)$ but increased BMI and waist circumference were significantly associated with increased occurance of NAFLD $(\mathrm{p}<0.05)$. Increased triglyceride and low HDL were significantly associated with both higher proportion and severity of NAFLD ( $\mathrm{p}<0.05)$. AST, ALT and AST: ALT, serum bilirubin and albumin level were within normal limit in all study population. Metabolic syndrome was significantly associated with NAFLD $(\mathrm{p}<0.05)$. After calculation of BAAT score 65\% T2DM patient with NAFLD had probable chance of fibrosis in liver. Conclusion: From this study it can be inferred that NAFLD is strongly associated with type2DM and metabolic syndrome and diabetic people should be kept under supervision and periodic clinical and laboratory evaluation to avoid progression of NAFLD to steatohepatitis and chronic liver disease.

Keywords: Type 2 diabetes mellitus, Non-alcoholic fatty liver disease, Hypertension, Dyslipidemia, Body mass index, Obesity, Metabolic syndrome, BAAT score.

Copyright @ 2020: This is an open-access article distributed under the terms of the Creative Commons Attribution license which permits unrestricted use, distribution, and reproduction in any medium for non-commercial use (NonCommercial, or CC-BY-NC) provided the original author and source are credited.

\section{INTRODUCTION}

Non-alcoholic fatty liver disease (NAFLD) is a condition that is characterised by excess deposition of fat in liver. This ranges from simple steatitis to steatohepatitis, cirrhosis and hepatocellular carcinoma
(HCC) [1]. Hypertension, diabetes, obesity and dyslipidemia are predisposing factors of NAFLD [2]. These are also considered as components of metabolic syndrome. NAFLD is supposed to be hepatic manifestation of metabolic syndrome $[3,2,4]$. Patients 
with NAFLD usually have insulin resistance (IR) which increases lipolysis from the adipose tissue [4], and there is an increased delivery of Free Fatty Acid (FFA) to the liver. These FFA either undergo lipid peroxidation or are esterified with glycerol to form triglycerides, leading to hepatic fat accumulation $[5,6]$. Though the mechanism is unclear by some intricated ways hypertension, central obesity and dyslipidaemia play their role as individual risk factor in the development of NAFLD. Non-alcoholic fatty liver disease (NAFLD) has become a public health problem worldwide due to rising incidence of obesity and Type 2 diabetes [7]. It has emerged as the commonest cause of chronic liver disease and abnormal liver function tests among adults in Western countries [3, 2, 4, 26]. The prevalence of Non-alcoholic fatty liver disease (NAFLD) varies in different population of study with a prevalence of $15 \%-$ $30 \%$ in Western populations $[8,9]$ and $9-40 \%$ in Asian countries [1]. The prevalence increases to $58 \%$ in overweight individuals and can be as high as $90 \%$ in obese individuals $[10,11]$. NAFLD is found in $60 \%$ of patients with mixed hyperlipidemia and in $83 \%$ of those with both mixed hyperlipidemia and an elevated serum alanine aminotransferase (ALT) [12, 13]. Increasing incidence of NAFLD is reported in Asian countries like Japan and China [14]. There is increased incidence of diabetes, obesity in India in last two decades, it is logical to expect increase in incidence of NAFLD in India $[15,16]$. Bangladesh is the next door neighbour of India and hence supposed to run the same risk. The prevalence of NAFLD in Type 2 DM patients is about $75 \%$ [3], and Diabetes mellitus is observed in 18\%$45 \%$ NAFLD patients [12, 13]. Compared with nondiabetic subjects, people with type 2 diabetes appear to have an increased risk of developing NAFLD and have a higher risk of developing fibrosis and cirrhosis [3, 2, 4]. The poor controlled diabetes promotes hepatic steatosis and a vicious cycle binds the two situations. So hepatic steatosis, diabetes, and metabolic syndrome are part of the same disease process ultimately leads to increased morbidity and mortality. Although about 70$75 \%$ of type 2 diabetic patients may have some form of NAFLD [17] precise prevalence of NAFLD in type 2 diabetes is unknown. Some small studies are available that are performed in highly selected populations and some studies have estimated prevalence of abnormal aminotransferase levels only [18-21]. An ultrasonographic study of patients with T2DM showed a $69 \%$ prevalence of NAFLD in Europe [22]. Diabetes as a disease has increased in an alarming way that has created a serious threat to public health globally and also in Bangladesh. We know NAFLD has strong association with diabetes mellitus so prevalence of NAFLD in Diabetes patients is a burning issue in Bangladesh. There is limited data on the prevalence of NAFLD from India [23-25]. Data on prevalence of NAFLD in diabetes patient is still lacking in Bangladesh. There are few studies of NAFLD in diabetic patients. Hence study is needed in the field to know prevalence and clinical spectrum of NAFLD in diabetic patients in our country. This study is an effort to find out ultrasonographic detection of NAFLD in Type 2 DM patients in tertiary level hospital in Bangladesh to see the prevalence of NAFLD and severity of it in Type 2 DM patients and other components of metabolic syndrome like hypertension, obesity and dyslipidaemia.

\section{STUdy OBJECTIVES General Objective}

a) To determine the proportion of NAFLD and metabolic syndrome in type 2 diabetes mellitus patients.

\section{Specific Objectives}

a) To find out the proportion of NAFLD in patients with type 2 diabetes mellitus by ultrasonography.

b) To evaluate the liver function tests among type 2 diabetes mellitus patients.

c) To find out proportion of metabolic syndrome among type 2 diabetes mellitus patients with or without NAFLD.

d) To calculate the BAAT score to find out high risk group among NAFLD who runs higher risk developing fibrosis in liver.

e) To find out relationship between NAFLD and its severity with associated risk factors in type 2 diabetic patients.

\section{Methodology}

This was a Cross sectional descriptive study carried out at medicine inpatient and outpatient department, Rajshahi Medical College Hospital, Rajshahi, Bangladesh done from July-2015 to June2017. The study population was adults with type $2 \mathrm{DM}$ attending in Medicine inpatient and outpatient department, Rajshahi Medical College Hospital, Rajshahi, Bangladesh. Sample Size: Ninety one cases of Type 2 DM patients and Purposive sampling method. Dependant and Independent variables: NAFLD, Metabolic syndrome, Age, Sex, Hypertension, BMI, Waist circumference, Duration of DM, Control of DM, Serum TG, Serum HDL cholesterol, Serum LDL cholesterol, Serum Total cholesterol, HbA1c, Serum AST, Serum ALT, AST: ALT and BAAT score.

\section{Inclusion Criteria}

Patients of both sexes

Patients diagnosed as type 2 diabetes mellitus.

\section{Exclusion Criteria}

Persons with previous history of jaundice

Patients with past history of alcohol consumption

Persons with history of chronic kidney disease and ischemic heart disease 
Patients with prior serologic evidence of HBV or HCV infection

Sample collection: Ninety one cases of type 2 DM were included in this study. The diagnosis of type 2 DM was based on performing FBS, PPBS and HbA1c and checking previous treatment records. After meeting the inclusion and exclusion criteria patients with type 2 DM admitted in inpatient department and attending outpatient department of medicine, Rajshahi medical college hospital was included in the study. Age of the patient ranged from 42 to 71 years. Among them 61 were male and 30 were female.

Operational definition: NAFLD: Nonalcoholic fatty liver disease (NAFLD) represents a spectrum of liver disease encompassing simple fatty infiltration (Steatosis), fat and inflammation (nonalcoholic steatohepatitis, NASH) and cirrhosis, in the absence of excessive alcohol consumption (typically a threshold of $<20 \mathrm{~g} /$ day for women and $<30 \mathrm{~g} /$ day for men).

Metabolic Syndrome: According to the NCEP ATP III definition, metabolic syndrome is present if three or more of the following five criteria are met: waist circumference over $90 \mathrm{~cm}$ (men) or $80 \mathrm{~cm}$ (women) for people of Asia pacific region, blood pressure $\geq 130 / 85 \mathrm{~mm} \mathrm{Hg}$, fasting triglyceride (TG) level $\geq 150 \mathrm{mg} / \mathrm{dl}$, fasting high density lipoprotein (HDL) cholesterol level less than $40 \mathrm{mg} / \mathrm{dl}$ (men) or 50 $\mathrm{mg} / \mathrm{dl}$ (women) and fasting blood glucose $\geq 110 \mathrm{mg} / \mathrm{dl}$.

Type 2 Diabetes Mellitus: Type 2 diabetes encompasses individuals who have insulin resistance and usually relative (rather than absolute) insulin deficiency. This form previously referred to as "noninsulin dependent diabetes" or "adult-onset diabetes." It accounts for $90-95 \%$ of all diabetes. Most but not all patients with type 2 diabetes mellitus are obese. Specific aetiologies of type 2 diabetes mellitus are not known.

\section{Procedure of Data collection}

Screening and recruitment: Patients were taken to a separate room where PI introduced himself and explained nature of study. A questionnaire and a written informed consent form (both in Bangla and English) was prepared. Patients were explained the nature of the study. Those who agreed to participate were recruited and detailed consent obtained. Data was obtained by PI from patient using the following methods.

\section{Clinical methodology}

- Socio-demographic data was obtained and a full medical history taken.

- A general physical examination was performed to look for stigmata of chronic liver disease.
- Blood pressure was measured with a mercury sphygmomanometer by applying the cuff around the left arm and readings were expressed in millimeters of mercury $(\mathrm{mm} \mathrm{Hg})$.

- Waist circumferance at the widest abdominal girth was measured using a measuring tape, reading was expressed in centimeters $(\mathrm{cm})$.

- Patients were examined for hepatomegaly, defined as a liver span in excess of $15 \mathrm{~cm}$.

- Height was measured in meter (m) using a measuring tape and weight in kilogram $(\mathrm{kg})$ without shoes using a weighing scale to determine and grade body mass index (BMI).

- Blood was drawn aseptically from the antecubital vein for liver function tests, lipid profile, HbA1c. Blood was sent for study and reports were collected.

- Patients were asked to perform abdominal ultrasonography.

BAAT Score Calculation: BAAT is an abbreviation for BMI, Age, ALT and serum triglyceride. These four parametres are used in a scoring system to identify individuals at high risk of septal fibrosis of liver. A score of 0 to 1 indicates low risk of fibrosis whereas a score of more than 1 suggests a high risk of septal fibrosis and hence liver biopsy may be useful in the later. The score are categorized as follows: BAAT score of study subjects with NAFLD, Ranged from 0-4.

The scores are categorized as follows: BMI $\left(\mathrm{kg} / \mathrm{m}^{2}\right): \geq 28=1, \quad<28=0$, Age: $\geq 50=1, \quad<50=0$, ALT $(\mathrm{U} / \mathrm{L}): \geq 2$ times rise than normal upper limit=1, $<2$ times rise than normal upper limit $=0$ and serum $\mathrm{TG}$ $(\mathrm{mg} / \mathrm{dl}): \geq 150=1,<150=0$.

Radiological methodology: The consultant radiologist in radiology and imaging department, Rajshahi medical college hospital performed B mode 2 dimensional abdominal Ultrasonography of all recruited patients with PI in attendance. Diagnosis of NAFLD was made on basis of criteria outlined below [20].

Procedure of Data Analysis: The numerical data obtained from the study was analyzed and the significance of differences was estimated by using statistical methods. After processing of all available information, statistical analysis was performed by using computer based SPSS-16 (Statistical Package for Social Science). Data was expressed in percentage, frequencies, mean and standard deviation. Continuous data was expressed as mean \pm standard deviation (SD) and dichotomous data was represented as percentage. Continuous variables were compared through the Student's t-test and for the categorical variables the chisquare test was applied. 


\section{RESULTS}

In this study maximum number of patients was in between 46-55 years of age and male female ratio was $2: 1$. Most of the patients with type $2 \mathrm{DM}$ were nonsmoker $(75.0 \%)$, normotensive $(68.2 \%)$. $78 \%$ patient were Muslim, 90\% patient were married, 70\% patient had monthly income $>15,000$ taka, 33\% patient were service holder, $33 \%$ patient were housewife and $22 \%$ were businessman, $55 \%$ patient were graduate [Table-1].

Table-1: Socio-demographic distribution of patients with type 2 DM (n=91)

\begin{tabular}{|c|c|c|c|}
\hline & & Frequency & $\%$ \\
\hline Age & $\begin{array}{c}\leq 45 \text { years } \\
46-55 \text { years } \\
56-65 \text { years } \\
>65 \text { years }\end{array}$ & $\begin{array}{c}6 \\
68 \\
10 \\
7\end{array}$ & $\begin{array}{c}6.5 \\
75.0 \\
11.0 \\
7.5 \\
\end{array}$ \\
\hline Sex & $\begin{array}{c}\text { Male } \\
\text { Female }\end{array}$ & $\begin{array}{l}61 \\
30\end{array}$ & $\begin{array}{l}67.0 \\
33.0\end{array}$ \\
\hline Smoking History & $\begin{array}{l}\text { Present } \\
\text { Absent }\end{array}$ & $\begin{array}{l}23 \\
68\end{array}$ & $\begin{array}{l}25.0 \\
75.0\end{array}$ \\
\hline Occupation & $\begin{array}{c}\text { Service holder } \\
\text { Businessman } \\
\text { Housewife } \\
\text { Others }\end{array}$ & $\begin{array}{l}30 \\
20 \\
30 \\
11\end{array}$ & $\begin{array}{l}33.0 \\
22.0 \\
33.0 \\
12.0\end{array}$ \\
\hline Religion & $\begin{array}{c}\text { Muslim } \\
\text { Non-Muslim }\end{array}$ & $\begin{array}{l}71 \\
20\end{array}$ & $\begin{array}{l}78.0 \\
22.0\end{array}$ \\
\hline Education & $\begin{array}{c}\text { Below primary } \\
\text { Up to HSC } \\
\text { Graduate }\end{array}$ & $\begin{array}{l}11 \\
30 \\
50\end{array}$ & $\begin{array}{l}12.0 \\
33.0 \\
55.0\end{array}$ \\
\hline Monthly income & $\begin{array}{l}<15000 \mathrm{Tk} \\
>15000 \mathrm{Tk}\end{array}$ & $\begin{array}{l}27 \\
64\end{array}$ & $\begin{array}{l}30.0 \\
70.0\end{array}$ \\
\hline Marital status & $\begin{array}{c}\text { Married } \\
\text { Unmarried }\end{array}$ & $\begin{array}{c}82 \\
9\end{array}$ & $\begin{array}{l}90.0 \\
10.0\end{array}$ \\
\hline
\end{tabular}

Table-2: Clinical variables of metabolic syndrome in patients with type 2 DM (n=91)

\begin{tabular}{|c|c|c|c|}
\hline & Frequency & $\%$ & Mean \pm SD \\
\hline \multicolumn{4}{|l|}{ BMI } \\
\hline Normal $\left(18.5-22.9 \mathrm{~kg} / \mathrm{m}^{2}\right)$ & 1 & 1.1 & \multirow[t]{3}{*}{$27.27 \pm 2.83$} \\
\hline Overweight $\left(23.0-24.9 \mathrm{~kg} / \mathrm{m}^{2}\right)$ & 17 & 18.7 & \\
\hline Obese $\left(>25.0 \mathrm{~kg} / \mathrm{m}^{2}\right)$ & 73 & 80.2 & \\
\hline \multicolumn{4}{|l|}{ Waist circumference } \\
\hline Normal $(<90 \mathrm{~cm}$ in male, $<80 \mathrm{~cm}$ in female $)$ & 32 & 35.2 & \multirow[t]{2}{*}{$102.22 \pm 8.01$} \\
\hline Increased ( $>90 \mathrm{~cm}$ in male, $>80 \mathrm{~cm}$ in female) & 59 & 64.8 & \\
\hline \multicolumn{4}{|l|}{ HTN } \\
\hline Present & 29 & 31.8 & \\
\hline Absent & 62 & 68.2 & \\
\hline
\end{tabular}

Mean BMI was $27.27 \pm 2.83 \mathrm{~kg} / \mathrm{m}^{2}$, mean WC was $102.22 \pm 8.01 \mathrm{~cm}$. In this study $18.7 \%$ patient was overweight and $80.2 \%$ were obese. Increased WC was observed in $64.8 \%$ patient. In this study mean SBP was
$127.47 \pm 12.72 \mathrm{~mm} \mathrm{Hg}$, mean DBP was $77.09 \pm 10.19$ $\mathrm{mm} \mathrm{Hg.} 68.2 \%$ study population were normotensive, $31.8 \%$ were hypertensive [Table-2].

Table-3: Investigation findings of patients with type 2 DM (n=91)

\begin{tabular}{|c|c|c|c|}
\hline \multirow{2}{*}{ HDL } & Frequency & $\%$ & Mean \pm SD \\
\hline & & & \\
\hline $\begin{array}{l}\text { Low }(<40 \mathrm{mg} / \mathrm{dl} \text { in male, }<50 \mathrm{mg} / \mathrm{dl} \text { in female) } \\
\text { Normal }(>40 \mathrm{mg} / \mathrm{dl} \text { in male, }>50 \mathrm{mg} / \mathrm{dl} \text { in female) }\end{array}$ & $\begin{array}{c}8 \\
83\end{array}$ & $\begin{array}{c}8.8 \\
91.2\end{array}$ & $41.85 \pm 2.72$ \\
\hline TG & & & \\
\hline $\begin{array}{l}\text { Normal }(<150 \mathrm{mg} / \mathrm{dl}) \\
\text { High }(\geq 150 \mathrm{mg} / \mathrm{dl})\end{array}$ & $\begin{array}{l}25 \\
66\end{array}$ & $\begin{array}{l}27 . .5 \\
72.5\end{array}$ & $186.08 \pm 58.42$ \\
\hline
\end{tabular}


In this study only $8.8 \%$ patient was found to have low HDL. $72.5 \%$ patient was found to have high TG, high LDL was found in $26 \%$ patient. Mean total cholesterol was $197.31 \pm 34.10 \mathrm{mg} / \mathrm{dl}$, mean LDL, HDL and TG was $114.18 \pm 35.41 \mathrm{mg} / \mathrm{dl}, 41.85 \pm 2.72 \mathrm{mg} / \mathrm{dl}$, and $186.08 \pm 58.42 \mathrm{mg} / \mathrm{dl}$ respectively [Table-3]. Mean AST, ALT, and AST: ALT, serum albumin and serum bilirubin was $29.47 \pm 5.89 \mathrm{U} / \mathrm{L}, 38.09 \pm 5.77 \mathrm{U} / \mathrm{L}, 0.077$ $\pm 0.08,3.80 .22 \mathrm{~g} / \mathrm{dl}$, and $0.45 \pm 0.09 \mathrm{mg} / \mathrm{dl}$ respectively.

Table-4: Components of metabolic syndrome NAFLD in patients with type 2 DM (n=91)

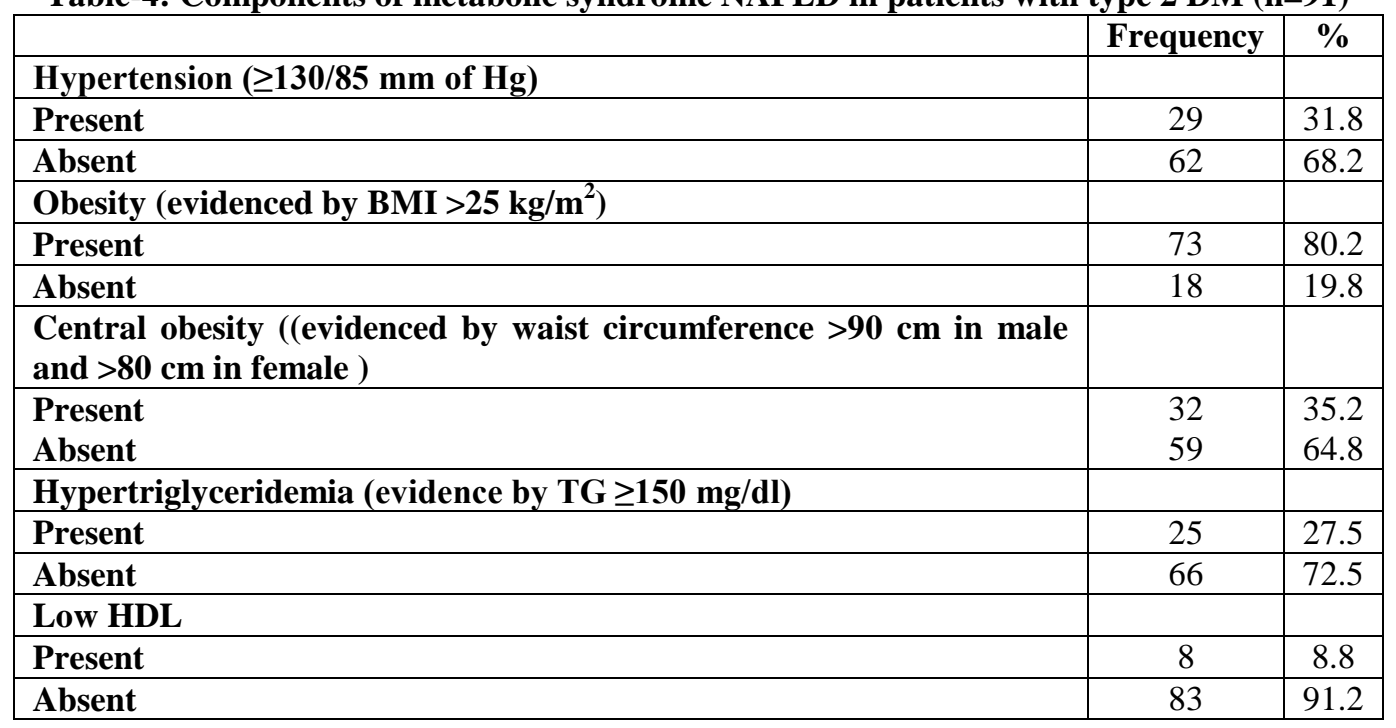

In this study proportion of hypertension, obesity, central obesity, hypertriglyceridemia and low
HDL were $31.8 \%, 80.2 \%, 35.2 \%, 72.5 \%, 8.8 \%$ respectively [Table-4].

Table-5: Patient categorization on the basis of single or multiple components of metabolic syndrome in patients with type 2 DM $(n=91)$

\begin{tabular}{|l|l|l|}
\hline Patient categorization & Frequency & \% \\
\hline Type 2 DM with only HTN & 29 & 31.8 \\
\hline Type 2 DM with obesity & 73 & 80.2 \\
\hline Type 2 DM with hypertriglyceridemia and low HDL & 66 & 72.5 \\
\hline Type 2 DM with HTN and obesity & 27 & 29.6 \\
\hline Type 2 DM with obesity, hypertriglyceridemia and low HDL & 61 & 67.03 \\
\hline Type 2 DM with HTN, obesity, hypertriglyceridemia and low HDL & 25 & 27.4 \\
\hline
\end{tabular}

Table 5 shows patient categorization on presence of different components of metabolic syndrome in type $2 \mathrm{DM}$ patients. It revealed $31.8 \%$ patient had type 2 DM with only HTN. $80.2 \%$ patient had type $2 \mathrm{DM}$ with obesity and $72.5 \%$ patient had type 2 DM with hypertriglyceridemia and low HDL. $29.6 \%$ patient had type 2 DM with HTN and obesity, $67.03 \%$ patient had type 2 DM with obesity and hypertriglyceridemia and low HDL where as $27.4 \%$ patient had type 2 DM with HTN, obesity and hypertriglyceridemia and low HDL [Table-5].

Table-6: Duration and control of diabetes mellitus in patients with type 2 DM (n=91)

\begin{tabular}{|l|l|l|l|}
\hline & Frequency & $\%$ & Mean \pm SD \\
\hline Duration of DM & & & \\
\hline 0-4 years & 23 & 25.0 & $7.44 \pm 4.21$ \\
5-9 years & 32 & 35.0 & \\
>9 years & 36 & 40.0 & \multirow{2}{|}{} \\
\cline { 1 - 3 } Control of DM & & \multicolumn{1}{|c}{} \\
\cline { 1 - 3 } Controlled & 29 & 31.8 & \\
Uncontrolled & 62 & 68.2 & \\
\cline { 1 - 3 }
\end{tabular}

NB: $\bar{x} \pm$ SD HbA1c was $6.96 \pm 1.17 \%$ 
In this study $(35.0+40.0) \%$ patients had patient DM was uncontrolled [Table-6]. diabetes more than 5 years and majority $(68.2 \%)$ of

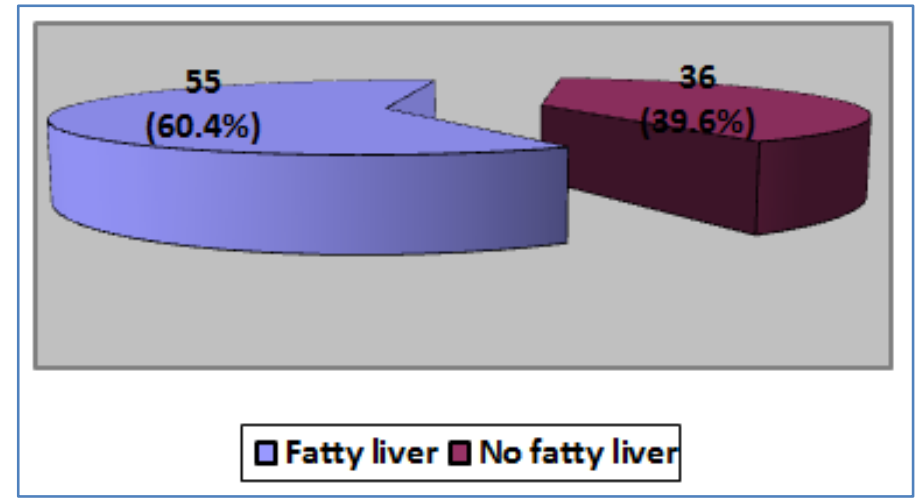

Fig-1: Proportion of fatty liver in patients with type 2 DM by abdominal ultrasonography (n=91).

In this study ultrasonographic proportion of NAFLD was $60.4 \%$ in patients with type 2 DM [Figure-1].

Table-7: Comparison of different clinical variables in diabetic patients with and without fatty liver $(\mathbf{n = 9 1 )}$

\begin{tabular}{|l|c|c|c|}
\hline \multirow{2}{*}{ Characteristics } & \multicolumn{2}{|c|}{ Type 2 Diabetes mellitus patients } & \multirow{2}{*}{ T, DF (P) } \\
\cline { 2 - 3 } & $\begin{array}{c}\text { With fatty liver } \\
\mathbf{n = 5 5}(\mathbf{m e a n} \pm \text { SD) }\end{array}$ & $\begin{array}{c}\text { Without fatty liver } \\
\mathbf{n = 3 6} \text { (mean } \pm \text { SD) }\end{array}$ & \\
\hline HbA1c & $7.282 \pm 1.26$ & $6.458 \pm 0.78$ & $3.478,89(0.000)$ \\
\hline BMI & $28.48 \pm 2.77$ & $25.40 \pm 1.69$ & $5.97,89(0.000)$ \\
\hline Waist circumference & $103.91 \pm 7.55$ & $99.64 \pm 8.11$ & $2.56,89(0.012)$ \\
\hline ALT & $38.29 \pm 6.10$ & $37.78 \pm 5.28$ & $0.413,89(0.681)$ \\
\hline AST & $29.44 \pm 5.65$ & $29.53 \pm 6.31$ & $-0.072,89(0.943)$ \\
\hline AST:ALT & $0.760 \pm 0.08$ & $0.770 \pm 0.80$ & $-0.32,89(0.749)$ \\
\hline
\end{tabular}

In this study demographic variables like BMI, waist circumference were significantly associated with presence of fatty liver in T2DM patients $(\mathrm{p}=0.000$ and $\mathrm{p}=0.000$ respectively). HbA1c was significantly associated with presence of NAFLD $(\mathrm{p}=0.000)$ but ALT, AST and AST: ALT were not significantly associated with presence of NAFLD in T2DM patients ( $\mathrm{p}=0.681, \mathrm{p}=0.943$ and $\mathrm{p}=0.749$ respectively) [Table-7].

Table-8: Relationship between NAFLD and age of patients with type 2 DM (n=91)

\begin{tabular}{|c|c|c|c|}
\hline & \multicolumn{2}{|c|}{ Ultrasonographic evidence of NAFLD } & \multirow{2}{*}{$\underset{\text { (p value) }}{\chi^{2} \text { test }}$} \\
\hline & $\begin{array}{c}\text { Present }(\mathbf{n}=55) \\
\text { No }(\%)\end{array}$ & $\begin{array}{c}\text { Absent }(\mathbf{n}=36) \\
\text { No }(\%)\end{array}$ & \\
\hline \multicolumn{4}{|l|}{ Age group } \\
\hline $\begin{array}{l}\leq 45 \text { years } \\
46-55 \text { years } \\
56-65 \text { years } \\
>65 \text { years }\end{array}$ & $\begin{array}{c}2(33.3) \\
39(57.4) \\
7(70.0) \\
7(100)\end{array}$ & $\begin{array}{c}4(66.7) \\
29(42.6) \\
3(30.0) \\
0(0.0)\end{array}$ & 0.069 \\
\hline Total & $55(60.4)$ & $36(39.6)$ & \\
\hline
\end{tabular}

In this study $33.3 \%$ patient $\leq 45$ years of age had NAFLD. $57.4 \%$ patient between $46-55$ years and $70.0 \%$ patients between 56-65 years of age had NAFLD and $100 \%$ patient $>65$ years had NAFLD. So higher prevalence of NAFLD was observed in higher age group but it was statistically just insignificant $\left(\chi^{2}=7.079, \mathrm{DF}=3, \mathrm{p}>0.05\right)$ [Table-8].

Table-9: Relationship between NAFLD and sex of the patients with type 2 DM (n=91)

\begin{tabular}{|c|c|c|c|}
\hline & \multicolumn{2}{|c|}{ Ultrasonographic evidence of NAFLD } & \multirow{2}{*}{$\underset{(p \text { value })}{\chi^{2} \text { test }}$} \\
\hline & $\begin{array}{c}\text { Present }(\mathbf{n}=55) \\
\text { No }(\%)\end{array}$ & $\begin{array}{c}\text { Absent }(\mathbf{n}=36) \\
\text { No }(\%)\end{array}$ & \\
\hline \multicolumn{4}{|l|}{ Sex } \\
\hline $\begin{array}{l}\text { Male } \\
\text { Female }\end{array}$ & $\begin{array}{l}36(59.0) \\
19(63.3)\end{array}$ & $\begin{array}{l}25(41.0) \\
11(36.7)\end{array}$ & 0.692 \\
\hline Total & $55(60.4)$ & $36(39.6)$ & \\
\hline
\end{tabular}


Ahmed Masiha Jamil et al; Saudi J Med Pharm Sci, Feb., 2020; 6(2): 186-200

In this study $59 \%$ male and $63.3 \%$ female had ultrasonographic evidence of NAFLD. So almost similar proportion of NAFLD was found in both male and female $\left(\chi^{2}=0.157, \mathrm{DF}=1, \mathrm{p}=0.692\right)$ [Table-9].

Table-10: Relationship between NAFLD and duration of DM in patients with T2DM (n=91)

\begin{tabular}{|c|c|c|c|}
\hline \multirow[t]{2}{*}{ Duration of DM } & \multicolumn{2}{|c|}{ Ultrasonographic evidence of fatty liver } & \multirow{2}{*}{$\begin{array}{l}\chi^{2} \text { test } \\
\text { (p value) }\end{array}$} \\
\hline & $\begin{array}{l}\text { Present }(n=55) \\
\text { No }(\%)\end{array}$ & $\begin{array}{l}\text { Absent }(n=36) \\
\text { No }(\%)\end{array}$ & \\
\hline 0-4 years & $11(47.8)$ & $12(52.2)$ & $<0.01$ \\
\hline $5-9$ years & $15(46.9)$ & $17(53.1)$ & \\
\hline$>9$ years & $29(80.6)$ & $7(19.4)$ & \\
\hline Total & $55(60.4)$ & $36(39.6)$ & \\
\hline
\end{tabular}

In this study $47.8 \%$ patient having DM $0-4$ years had NAFLD. 47.9\% patient having DM 5-9 years and $80.6 \%$ having DM $>9$ years had NAFLD. So increased duration of DM was significantly associated with higher prevalence of NAFLD $\left(\chi^{2}=10.086, \mathrm{DF}=2\right.$, $\mathrm{p}<0.01)$ [Table-10].

Table-11: Relationship between NAFLD and presence of HTN in patients with type 2 DM (n=91)

\begin{tabular}{|l|l|l|l|}
\hline \multirow{2}{*}{} & \multicolumn{2}{|l|}{ Ultrasonographic evidence of NAFLD } & $\begin{array}{l}\chi^{2} \text { test } \\
\text { (p value) } \\
\text { No (\%) }\end{array}$ \\
\hline HTN & & $\begin{array}{l}\text { Absent }(\mathbf{n}=36) \\
\text { No }(\%)\end{array}$ & \\
\hline Present & $20(68.9)$ & & 0.255 \\
Absent & $35(56.5)$ & $9(31.1)$ & \\
\hline Total & $55(60.4)$ & $27(43.5)$ & \\
\hline
\end{tabular}

In this study68.9\% patient who were hypertensive had ultrasonographic evidence of NAFLD and $56.5 \%$ who were not hypertensive had NAFLD. HTN was not significantly associated with higher prevalence of NAFLD $\left(\chi^{2}=1.294, \mathrm{DF}=1, \mathrm{p}=0.255\right)$ [Table-11].

Table-12: Relationship between NAFLD and BMI patients with type 2 DM (n=91)

\begin{tabular}{|c|c|c|c|}
\hline & \multicolumn{2}{|c|}{ Ultrasonographic evidence of NAFLD } & \multirow{2}{*}{$\begin{array}{l}\chi^{2} \text { test } \\
\text { (p value) }\end{array}$} \\
\hline & $\begin{array}{l}\text { Present }(\mathrm{n}=55) \\
\text { No }(\%)\end{array}$ & $\begin{array}{l}\text { Absent }(\mathrm{n}=36) \\
\text { No }(\%)\end{array}$ & \\
\hline \multicolumn{4}{|l|}{ BMI } \\
\hline $\begin{array}{l}\text { Normal }\left(18.5-22.9 \mathrm{~kg} / \mathrm{m}^{2}\right) \\
\text { Overweight }\left(23-24.9 \mathrm{~kg} / \mathrm{m}^{2}\right) \\
\text { Obese }\left(>25 \mathrm{~kg} / \mathrm{m}^{2}\right)\end{array}$ & $\begin{array}{l}0(0) \\
1(5.9) \\
54(73.9)\end{array}$ & $\begin{array}{l}1(100) \\
16(94.1) \\
19(26.1)\end{array}$ & $<0.001$ \\
\hline Total & $55(60.4)$ & $36(39.6)$ & \\
\hline
\end{tabular}

In these study $73.9 \%$ obese patients and $5.9 \%$ overweight patient had ultrasonographic evidence of NAFLD. So obesity was significantly associated with higher prevalence of NAFLD in patients with type 2 $\mathrm{DM}\left(\chi^{2}=28.282, \mathrm{DF}=2, \mathrm{p}=<0.001\right)$ [Table-12].

Table-13: Relationship between NAFLD and waist circumferance in patients with type 2 DM (n=91)

\begin{tabular}{|c|c|c|c|}
\hline & \multicolumn{2}{|c|}{ Ultrasonographic evidence of NAFLD } & \multirow{2}{*}{$\begin{array}{l}\chi^{2} \text { test } \\
\text { (p value) }\end{array}$} \\
\hline & $\begin{array}{l}\text { Present }(\mathrm{n}=55) \\
\text { No }(\%)\end{array}$ & $\begin{array}{l}\text { Absent }(\mathrm{n}=36) \\
\text { No }(\%)\end{array}$ & \\
\hline \multicolumn{4}{|l|}{ Waist circumference } \\
\hline $\begin{array}{l}\text { Normal }(<90 \mathrm{~cm} \text { in male, }<80 \mathrm{~cm} \text { in female) } \\
\text { Increased }(>90 \mathrm{~cm} \text { in male, }>80 \mathrm{~cm} \text { in female) }\end{array}$ & $\begin{array}{l}10(31.3) \\
45(76.2)\end{array}$ & $\begin{array}{l}22(68.7) \\
14(23.8)\end{array}$ & $<0.001$ \\
\hline Total & $55(60.4)$ & $36(39.6)$ & \\
\hline
\end{tabular}

In this study $76.2 \%$ patient with increased waist circumference had ultrasonographic evidence of NAFLD. Only $31.3 \%$ patient with normal waist circumference had ultrasonographic evidence of
NAFLD. So increased waist circumference was significantly associated with higher prevalence of NAFLD in patients with type $2 \mathrm{DM}\left(\chi^{2}=17.588, \mathrm{DF}=1\right.$, $\mathrm{p}=<0.001$ ) [Table-13]. 
Ahmed Masiha Jamil et al; Saudi J Med Pharm Sci, Feb., 2020; 6(2): 186-200

Table-14: Relationship between NAFLD and LDL level in patients with type 2 DM (n=91)

\begin{tabular}{|c|c|c|c|}
\hline & \multicolumn{2}{|c|}{ Ultrasonographic evidence of NAFLD } & \multirow{2}{*}{$\begin{array}{l}\chi^{2} \text { test } \\
\text { (p value) }\end{array}$} \\
\hline & $\begin{array}{l}\text { Present }(n=55) \\
\text { No }(\%)\end{array}$ & $\begin{array}{l}\text { Absent }(\mathbf{n}=36) \\
\text { No }(\%)\end{array}$ & \\
\hline \multicolumn{4}{|l|}{ LDL } \\
\hline Optimal (<100 mg/dl) & $25(51.0)$ & $24(49.0)$ & \\
\hline Near optimal (100-129 mg/dl) & $13(72.2)$ & $5(27.8)$ & 0.405 \\
\hline Borderline high (130-159 mg/dl) & $4(66.7)$ & $2(33.3)$ & \\
\hline High $(160-189 \mathrm{mg} / \mathrm{dl})$ & $8(72.7)$ & $3(27.3)$ & \\
\hline Very high $(\geq 190 \mathrm{mg} / \mathrm{dl})$ & $5(71.4)$ & $2(28.6)$ & \\
\hline Total & $55(60.4)$ & $36(39.6)$ & \\
\hline
\end{tabular}

In this study $71.4 \%$ patient with very high and $72.2 \%$ patient with high LDL level had ultrasonographic evidence of NAFLD. Again 51\% patient with optimal, $72.2 \%$ patient with near optimal and $66.7 \%$ patient with borderline high LDL level had ultrasonographic evidence of NAFLD. So no significant association was found between LDL level and prevalence of NAFLD in patients with type 2 DM $\left(\chi^{2}=4.009, \mathrm{DF}=4, \mathrm{p}=0.405\right)$ [Table-14].

Table-15: Relationship between NAFLD and HDL level in patients with type 2 DM (n=91)

\begin{tabular}{|c|c|c|c|}
\hline & \multicolumn{2}{|c|}{ Ultrasonographic evidence of NAFLD } & \multirow{2}{*}{$\begin{array}{l}\chi^{2} \text { test } \\
(\mathbf{p} \text { value })\end{array}$} \\
\hline & $\begin{array}{l}\text { Present }(n=55) \\
\text { No }(\%)\end{array}$ & $\begin{array}{l}\text { Absent }(n=36) \\
\text { No }(\%)\end{array}$ & \\
\hline \multicolumn{4}{|l|}{ HDL } \\
\hline $\begin{array}{l}\text { Low }(<40 \mathrm{mg} / \mathrm{dl} \text { in male, }<50 \mathrm{mg} / \mathrm{dl} \text { in female) } \\
\text { Normal }(>40 \mathrm{mg} / \mathrm{dl} \text { in male, }>50 \mathrm{mg} / \mathrm{dl} \text { in female) }\end{array}$ & $\begin{array}{l}8(100) \\
47(56.6)\end{array}$ & $\begin{array}{l}0(0) \\
36(43.4)\end{array}$ & $<0.05$ \\
\hline Total & $55(60.4)$ & $36(39.6)$ & \\
\hline
\end{tabular}

In this study $100 \%$ patient with low HDL level had NAFLD. So all patients with low HDL was found to have NAFLD and it is statistically significant $\left(\chi^{2}=5.741, \mathrm{DF}=1, \mathrm{p}=<0.05\right)$ [Table-15].

Table-16: Relationship between NAFLD and total cholesterol level in patients with type 2 DM (n=91)

\begin{tabular}{|l|l|l|l|}
\hline \multirow{2}{*}{} & \multicolumn{2}{|l|}{ Ultrasonographic evidence of NAFLD } & \multirow{2}{*}{$\begin{array}{l}\mathbf{2} \text { test } \\
\text { (p value) }\end{array}$} \\
\cline { 2 - 3 } & $\begin{array}{l}\text { Present }(\mathbf{n = 5 5}) \\
\text { No (\%) }\end{array}$ & $\begin{array}{l}\text { Absent (n=36) } \\
\text { No }(\%)\end{array}$ & \\
\hline Total cholesterol & & & $<0.01$ \\
\hline Desirable $(<200 \mathrm{mg} / \mathrm{dl})$ & $30(49.2)$ & $31(50.8)$ & \\
Borderline high $(200-239 \mathrm{mg} / \mathrm{dl})$ & $16(84.2)$ & $3(15.8)$ & \\
High $(\geq 240 \mathrm{mg} / \mathrm{dl})$ & $9(81.8)$ & $2(18.2)$ & \\
\hline Total & $55(60.4)$ & $36(39.6)$ & \\
\hline
\end{tabular}

In this study $81.8 \%$ patient with high and $84.2 \%$ patient with borderline high level of serum total cholesterol had ultrasonographic evidence of NAFLD. 49.2\% patient with NAFLD had desirable level of serum cholesterol. So higher level of total cholesterol was significantly associated with higher prevalence of NAFLD $\left(\chi^{2}=9.827, \mathrm{DF}=2, \mathrm{p}=<0.01\right)$ [Table-16].

Table-17: Relationship between NAFLD and TG level in patients with type 2 DM (n=91)

\begin{tabular}{|c|c|c|c|}
\hline & \multicolumn{2}{|c|}{ Ultrasonographic evidence of NAFLD } & \multirow{2}{*}{$\begin{array}{l}\chi^{2} \text { test } \\
\text { (p value) }\end{array}$} \\
\hline & $\begin{array}{l}\text { Present }(\mathrm{n}=55) \\
\text { No }(\%)\end{array}$ & $\begin{array}{l}\text { Absent }(\mathbf{n}=36) \\
\text { No }(\%)\end{array}$ & \\
\hline \multicolumn{4}{|l|}{ TG } \\
\hline $\begin{array}{l}\text { Normal }(<150 \mathrm{mg} / \mathrm{dl}) \\
\text { High }(\geq 150 \mathrm{mg} / \mathrm{dl})\end{array}$ & $\begin{array}{l}10(40.0) \\
45(68.2)\end{array}$ & $\begin{array}{l}15(60.0) \\
21(31.8)\end{array}$ & $<0.05$ \\
\hline Total & $55(60.4)$ & $36(39.6)$ & \\
\hline
\end{tabular}

In this study $68.2 \%$ patient with high level of TG had ultrasonographic evidence of NAFLD. Higher TG level was significantly associated with higher prevalence of NAFLD $\left(\chi^{2}=6.023, \mathrm{DF}=1, \mathrm{p}=<0.05\right)$ [Table-17]. 


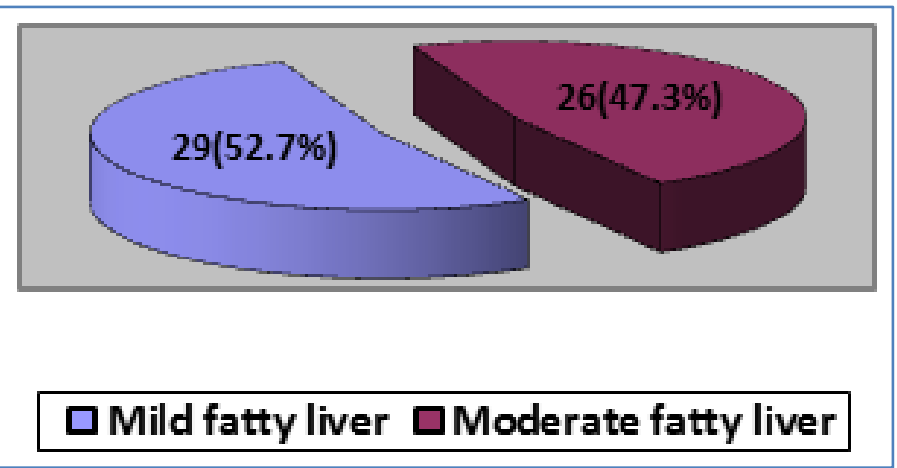

Fig-2: Severity of NAFLD on basis of Ultrasonography in patients with type 2 DM $(n=55)$

In this study $29(52.7 \%)$ had mild fatty change in liver and $26(47.3 \%)$ had moderate fatty change in liver on ultrasonography in patients of T2DM with NAFLD [Figure-2].

Table-18: Relationship between severity of NAFLD and presence of HTN in patients with type 2 DM (n=55)

\begin{tabular}{|c|c|c|c|}
\hline & \multicolumn{2}{|c|}{ Severity of NAFLD } & \multirow{2}{*}{$\begin{array}{l}\chi^{2} \text { test } \\
\text { (p value) }\end{array}$} \\
\hline & $\begin{array}{l}\text { Mild }(n=29) \\
\text { No }(\%)\end{array}$ & $\begin{array}{l}\text { Moderate }(n=26) \\
\text { No }(\%)\end{array}$ & \\
\hline \multicolumn{4}{|l|}{ HTN } \\
\hline $\begin{array}{l}\text { Present } \\
\text { Absent }\end{array}$ & $\begin{array}{l}8(40.0) \\
(27.6) \\
21(60.0) \\
(72.4)\end{array}$ & $\begin{array}{l}12(60.0) \\
(46.2) \\
14(40.0) \\
(53.8)\end{array}$ & 0.153 \\
\hline Total & $\begin{array}{l}29(52.7) \\
(100)\end{array}$ & $\begin{array}{l}26(47.3) \\
(100)\end{array}$ & \\
\hline
\end{tabular}

In this study $40.0 \%$ patient who were hypertensive had mild and $60.0 \%$ patient who were hypertensive had moderate from of NAFLD. $72.4 \%$ patient who had mild fatty change and $53.8 \%$ patient who had moderate fatty change were not hypertensive.
No significant association was found between HTN and severity of NAFLD $\left(\chi^{2}=2.042, \mathrm{DF}=1, \mathrm{p}=0.153\right)$ [Table$18]$.

Table-19: Relationship between severity of NAFLD and BMI patients with type 2 DM (n=55)

\begin{tabular}{|l|l|l|l|}
\hline \multirow{2}{*}{} & \multicolumn{2}{|l|}{ Severity of NAFLD } & $\begin{array}{l}\boldsymbol{\chi}^{\mathbf{2}} \text { test } \\
\text { (p value) }\end{array}$ \\
\cline { 2 - 4 } & $\begin{array}{l}\text { Mild }(\mathbf{n = 2 9}) \\
\text { No }(\%)\end{array}$ & $\begin{array}{l}\text { Moderate }(\mathbf{n}=26) \\
\text { No }(\%)\end{array}$ & \\
\hline BMI & & & \\
\hline Overweight & $1(100)$ & $0(0)$ & 0.339 \\
& $(3.4)$ & $0(0)$ & \\
Obese & $\begin{array}{l}28(51.8) \\
(96.6)\end{array}$ & $\begin{array}{l}26(48.2) \\
(100)\end{array}$ & \\
\hline Total & $29(52.7)$ & $26(47.3)$ & \\
& $(100)$ & $(100)$ & \\
\hline
\end{tabular}

In this study $100 \%$ overweight patient had mild and $51.8 \%$ obese patient had mild and $48.2 \%$ obese patient had moderate form of NAFLD.96.6\% who had mild fatty change and $100 \%$ patient had moderate fatty change in liver were obese. No significant association was found between obesity and severity of NAFLD $\left(\chi^{2}=0.913, \mathrm{DF}=1, \mathrm{p}=0.339\right)$ [Table-19]. 
Table-20: Relationship between severity of NAFLD and HDL level in patients with type 2 DM $(\mathbf{n = 5 5})$

\begin{tabular}{|l|l|l|l|}
\hline \multirow{2}{*}{} & \multicolumn{2}{|l|}{ Severity of NAFLD } & $\chi^{\mathbf{2}}$ test \\
\cline { 2 - 3 } & $\begin{array}{l}\text { Mild (n=29) } \\
\text { No (\%) }\end{array}$ & $\begin{array}{l}\text { Moderate (n=26) } \\
\text { No (\%) }\end{array}$ & \\
\hline HDL & & & \\
\hline Low & $1(12.5)$ & $7(87.5)$ & $<0.05$ \\
& $(3.4)$ & $(26.3)$ & \\
Normal & $28(59.5)$ & $19(40.5)$ & \\
& $(96.6)$ & $(73.7)$ & \\
\hline Total & $29(52.7)$ & $26(47.3)$ & \\
& $(100)$ & $(100)$ & \\
\hline
\end{tabular}

In this study $12.5 \%$ with low HDL level had moderate and $87.5 \%$ with low HDL had moderate form of NAFLD. $26.3 \%$ patient who had moderate fatty change and $3.4 \%$ patient who had mild fatty change had low HDL level. Low HDL was significantly associated with more severe form of NAFLD $\left(\chi^{2}=6.078, \mathrm{DF}=1, \mathrm{p}=\right.$ $<0.05)$ [Table-20].

Table-21: Relationship between severity of NAFLD and TG level in patients with type 2 DM (n=55)

\begin{tabular}{|l|l|l|l|}
\hline \multirow{2}{*}{} & \multicolumn{2}{|l|}{ Severity of NAFLD } & $\boldsymbol{\chi}^{\mathbf{2}}$ test \\
\cline { 2 - 3 } & $\begin{array}{l}\text { Mild (n=29) } \\
\text { No }(\boldsymbol{\%})\end{array}$ & $\begin{array}{l}\text { Moderate }(\mathbf{n}=26) \\
\text { No }(\%)\end{array}$ & \\
\hline TG & & & \\
\hline Normal & $10(100)$ & $0(0)$ & $<0.01$ \\
& $(34.5)$ & $0(0)$ & \\
High & $19(42.3)$ & $26(57.7)$ & \\
& $(65.5)$ & $(100)$ & \\
\hline Total & $29(52.7)$ & $26(47.3)$ & \\
& $(100)$ & $(100)$ & \\
\hline
\end{tabular}

In this study $42.3 \%$ patient with high TG had mild and $57.7 \%$ patient with high $\mathrm{TG}$ had moderate form of NAFLD. $100 \%$ patient who had moderate fatty change and $65.5 \%$ patient who had mild fatty change were had high TG level. High TG level was significantly associated with more severe form of NAFLD $\left(\chi^{2}=10.958, \mathrm{DF}=1, \mathrm{p}=<0.01\right)$ [Table-21].

Table-22: Relationship between severity of NAFLD and DM control in patients with type 2 DM (n=55)

\begin{tabular}{|c|c|c|c|}
\hline & \multicolumn{2}{|c|}{ Severity of NAFLD } & \multirow{2}{*}{$\begin{array}{l}\chi^{2} \text { test } \\
\text { (p value) }\end{array}$} \\
\hline & $\begin{array}{l}\text { Mild }(\mathbf{n}=29) \\
\text { No }(\%)\end{array}$ & $\begin{array}{l}\text { Moderate }(\mathrm{n}=26) \\
\text { No }(\%)\end{array}$ & \\
\hline \multicolumn{4}{|l|}{ DM control } \\
\hline Controlled & $12(92.3)$ & $1(7.7)$ & \\
\hline Uncontrolled & $17(40.5)$ & $25(59.5)$ & $<0.01$ \\
\hline Total & $29(52.7)$ & $26(47.3)$ & \\
\hline
\end{tabular}

In this study $40.5 \%$ patient with uncontrolled was significantly associated with more severe NAFLD DM had mild and 59.5\% patient with uncontrolled DM had moderate form of NAFLD. So uncontrolled DM $\left(\chi^{2}=10.700, \mathrm{DF}=1, \mathrm{p}=<0.01\right)[$ Table-22].

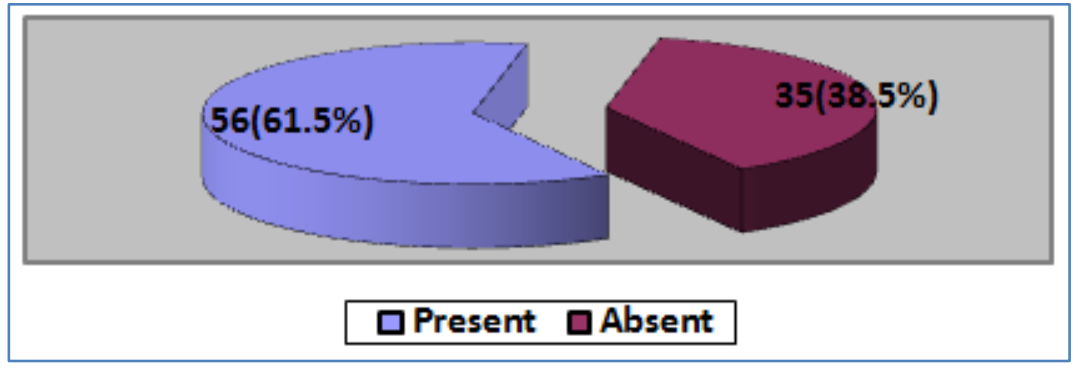

Fig-3: Proportion of metabolic syndrome in patients with type 2 DM (n=91)

In this study proportion metabolic syndrome in patients with type 2 DM was $61.5 \%$ [Figure-3]. 


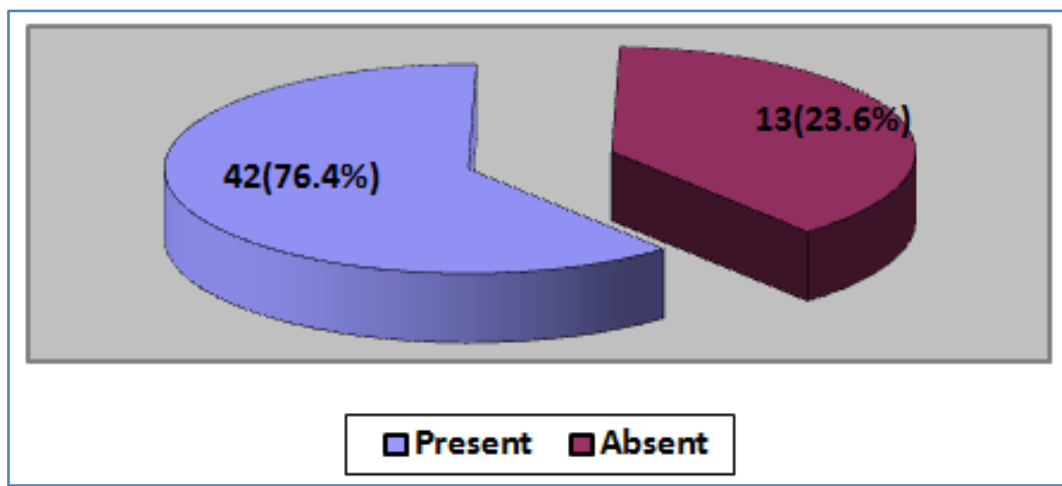

Fig-4: Proportion of metabolic syndrome in patients with type 2 DM with NAFLD $(n=55)$

In this study proportion of metabolic syndrome in patients with type 2 DM with NAFLD was 76.4\% [Figure-4].

Table-23: Relationship between NAFLD and metabolic syndrome in patients with T2DM (n=91)

\begin{tabular}{|c|c|c|c|}
\hline \multirow[t]{2}{*}{ Metabolic syndrome } & \multicolumn{2}{|c|}{ Ultrasonographic evidence of fatty liver } & \multirow{2}{*}{$\begin{array}{l}\chi^{2} \text { test } \\
\text { (p value) }\end{array}$} \\
\hline & $\begin{array}{l}\text { Present }(n=55) \\
\text { No }(\%)\end{array}$ & $\begin{array}{l}\text { Absent }(n=36) \\
\text { No }(\%)\end{array}$ & \\
\hline $\begin{array}{l}\text { Present } \\
\text { Absent }\end{array}$ & $\begin{array}{l}42(75.0) \\
13(37.2)\end{array}$ & $\begin{array}{l}14(25.0) \\
22(62.8)\end{array}$ & $<0.001$ \\
\hline Total & $55(60.4)$ & $36(39.6)$ & \\
\hline
\end{tabular}

In this study $75.0 \%$ patient with ultrasonographic evidence of NAFLD had metabolic syndrome. Metabolic syndrome was significantly associated with NAFLD in patients with T2DM $\left(\chi^{2}=\right.$ 12.910, $\mathrm{DF}=1, \mathrm{p}<0.001)$ [Table-23].

Table-24: Probability of fibrosis of liver according to BAAT score calculation in patients with type 2 DM having ultrasonographic evidence of NAFLD $(\mathbf{n}=55)$

\begin{tabular}{|l|l|l|}
\hline & Frequency & \% \\
\hline BAAT score & & \\
\hline No fibrosis $(<2)$ & 19 & 35.0 \\
Possible fibrosis $(\geq 2)$ & 36 & 65.0 \\
\hline
\end{tabular}

Among the patient of type $2 \mathrm{DM}$ having ultrasonographic evidence of NAFLD 19(35\%) patients were found to have no probability of fibrosis (having BAAT score $(<2)$ and $36(65 \%)$ patients were found to have probability of fibrosis in liver (having BAAT score $\geq 2$ ) [Table-24].

\section{DisCUSSION}

NAFLD is characterized by fatty infiltration of the liver mostly in the form of triglyceride which exceeds $5 \%$ of the liver weight without a history of significant alcohol intake and not due to other identifiable causes of liver [3]. Fatty liver is a common finding among T2DM individuals. NAFLD and T2DM together have poorer prognosis in terms of higher frequency of cirrhosis and mortality [27]. NAFLD is more commonly seen in T2DM patients and it is now an important public health issue. NAFLD is associated with a variety of features of metabolic syndrome like obesity, hypertension and hypertriglyceridemia and low HDL. NAFLD is the integral part of the metabolic syndrome which comprises a cluster of abnormalities such as hyperglycemia, hypertriglyceridemia and low HDL, hypertension, obesity with insulin resistance as a central pathogenic factor [28]. This cross sectional descriptive study was conducted in medicine department, Rajshahi medical college. This study was designed to determine the ultrasonographic proportion of NAFLD in subjects with T2DM. UIltrasonography has a sensitivity and specificity of $83 \%$ and $100 \%$ respectively as compared with histological finding as the gold standard method in detecting fatty liver $[29,30]$. Ultrasonography is a validated tool for screening of NAFLD in the absence of liver biopsy [3133]. Ninety one patients with T2DM were included in this study who met the inclusion criteria and who were admitted in inpatient or attended outpatient department of medicine in Rajshahi medical college hospital. Out of the five components of metabolic syndrome, diabetes is the risk factor most frequently associated with NAFLD. This study further documented the proportion of the other components of metabolic syndrome namely obesity, elevated blood pressure, elevated triglyceride and low HDL cholesterol and we tried to determine if there was significant association of these factors to NAFLD in study subjects. Liver function tests were also done to asses any derangement. The study population was mostly urban, middle class, living and 
working in Rajshahi and from diverse occupational background. In this study age range of study population was 42 to 71 years and most study subjects were in between $46-55$ years of age. Mean age of the study population $51-43 \pm 6.24$ years. Among ninety one study population sixty one were male and thirty were female. Male female ratio was 2:1. $78 \%$ patient were Muslim, $90 \%$ patient were married, $70 \%$ patient had monthly income $>15,000$ taka, 33\% patient were service holder, $33 \%$ patient were housewife and $22 \%$ were businessman, $55 \%$ patient were graduate. Most of the study population were nonsmoker (75.0\%), normotensive (68.2\%).In this study mean SBP was $127.47 \pm 12.72 \mathrm{~mm} \mathrm{Hg}$ and mean DBP was $77.09 \pm 10.19$ $\mathrm{mm} \mathrm{Hg.} 18.7 \%$ patient was overweight and increased waist circumferance was observed in $64.8 \%$ patient. Among study population twenty nine patients were hypertensive. Prevalence of HTN in T2DM patient with or without NAFLD was $31.8 \%$. Seventy three T2DM patients were obese. Prevalence of obesity in T2DM patient with or without NAFLD was $80.2 \%$. Sixty six patients had high TG level. So prevalence of hypertriglyceridemia and low HDL as evidenced by high TG level in T2DM patient with or without NAFLD was $72.5 \% .31 .8 \%$ patient had type 2 DM with only HTN. $80.2 \%$ patient had type 2 DM with obesity and $72.5 \%$ patient had type 2 DM with hypertriglyceridemia and low HDL. $29.6 \%$ patient had type 2 DM with HTN and obesity, $67.03 \%$ patient had type 2 DM with obesity and hypertriglyceridemia and low HDL where as $27.4 \%$ patient had type 2 DM with HTN, obesity and hypertriglyceridemia and low HDL. In this study 55 patients out of 91 had ultrasonographic evidence of NAFLD. Proportion of NAFLD in T2DM was $60.4 \%$ in this study by ultrasonography. The diagnosis of NAFLD in the current study was solely based on abdominal ultrasonography. Ultrasonography was considered famous and common clinical procedure to diagnose NAFLD which precisely diagnosed steatosis with a sensitivity of upto $80 \%$ [34, 20] [35], found proportion of NAFLD was $61 \%$ among T2DM population detected by abdominal ultrasound which is almost similar to our study and [36], found $60.8 \%$ ultrasonographic occurrence of NAFLD in T2DM patients which was also similar to our study result. This study was found proportion of NAFLD among T2DM patients in their study as $55.68 \%, 56.66 \%, 58.5 \%, 62 \%$, $55.8 \%$ respectively [27]. All these studies were conducted in India and neighboring Japan and the prevalence rate was almost similar to our study. On the other hand [37], found $30.5 \%$ and $10.51 \%$ ultrasonographic presence of NAFLD in T2DM patients which were much lower than our study result. In this study $52.7 \%$ patient had mild fatty change and $47.3 \%$ had moderate fatty changes in liver on ultrasonography. [38], also found 52\% mild and 36\% moderate fatty changes on USG which nearly matched our study. In this study mean age of study population was $51.43 \pm$ 6.24 years and mean age of patients in both NAFLD and non NAFLD with T2DM patients was 53.24 \pm 6.86 years and $48.67 \pm 3.81$ years respectively which was statistically significant $(\mathrm{p}=0.000)$. Higher mean age was found by $[38,35]$. Lower age was found by Singh et al. In this study [38], found no statistically significant difference in age between T2DM patients with and without NAFLD but [35], found significant difference between mean age of two group $(\mathrm{p}=0.002)$.

In this study, it was found that increased proportion of NAFLD was observed in higher age group but it was not statistically significant $(\mathrm{p}>0.05)$. In this study among study population, majority $(75 \%)$ had diabetes more than 5 years with a mean duration $7.44 \pm 4.21$ years. Longer duration of DM was significantly associated with higher proportion of NAFLD $(\mathrm{p}<0.01)$. And also found longer duration of DM was significantly associated with increased occurrence of NAFLD ( $\mathrm{p}<0.001)$ [44]. This study found statistically significant association between increased duration of $\mathrm{DM}$ and presence of fatty liver $(\mathrm{p}=0.001$, $p<0.001$ and $p<0.0001$ respectively) $[37,38]$, and found no significant relationship between duration of DM and presence of fatty liver $(\mathrm{p}=0.45$ and $\mathrm{p}=0.81$ respectively). But [27], found mean duration of DM was significantly lower in patients with NAFLD as compared to patient without NAFLD ( $p=0.002)$. In this study found most of the study population with NAFLD had prolonged course of DM [39]. Found mean duration of DM was $12 \pm 3$ years among T2DM patient with NAFLD which was statistically significant $(p<0.001)$ [40]. In this study $68.2 \%$ patient had uncontrolled DM and uncontrolled DM was significantly associated with more severe form of NAFLD $(\mathrm{p}<0.01)$. In this study control of DM was indicated by measurement of HbA1c. Mean HbA1c was $6.96 \pm 1.17 \%$ among study population and HbA1c was $7.282 \pm 1.26 \%$ and $6.45 \pm 0.78 \%$ among NAFLD and non NAFLD patients with T2DM respectively which was statistically significant $(p=0.000)$. And found control of DM was significantly associated with presence of fatty liver ( $\mathrm{p}<0.001)$. And found $\mathrm{HbA1c}$ level was significantly higher in diabetic patients with fatty liver in comparison to non-fatty liver diabetic patients $(p<0.0001)[37,41]$. But [35], found control of DM was not significantly associated with occurrence of NAFLD in T2DM. FPG and HbA1c statistically did not differ between NAFLD and non NAFLD study population $(\mathrm{p}=0.751$ and $\mathrm{p}=0.064$ respectively). Also found significant relation between uncontrolled DM and fatty change in liver. In this study HTN was not significantly associated with higher proportion of NAFLD $(\mathrm{p}=0.255)$ and severity of NAFLD ( $\mathrm{p}=0.153)$ [39]. Also found presence of HTN in T2DM patient with or without NAFLD was not statistically significant with occurrence of NAFLD. The found that hypertension which is an important component of metabolic syndrome was significantly associated with presence of fatty change in liver in T2DM patients $(\mathrm{p}=0.001, \mathrm{p}=0.004, \mathrm{p}<0.0001, \mathrm{p}<0.001$ 
respectively) [40, 41, 44, 37]. In this study mean BMI was $27.27 \pm 2.83 \mathrm{~kg} / \mathrm{m}^{2}$ and mean waist circumferance was $102.22 \pm 8.01 \mathrm{~cm}$ among study population, $80.2 \%$ of study population were obese. Mean BMI among NAFLD and non NAFLD with T2DM was $28.48 \pm 2.77$ $\mathrm{cm}$ and $25.40 \pm 1.69 \mathrm{~cm}$ respectively which was statistically significant $(\mathrm{p}=0.000)$. In this study obesity was significantly associated with increased occurrence of NAFLD in T2DM $(\mathrm{p}<0.001)$, but no significant association was found between obesity and severity of NAFLD ( $\mathrm{p}=0.339)$. Mean waist circumferance among study population was $102.22 \pm 8.01 \mathrm{~cm}$. Mean waist circumferance among NAFLD and non NAFLD with T2DM was $103.91 \pm 7.55 \mathrm{~cm}$ and $99.64 \pm 8.11 \mathrm{~cm}$ respectively which was statistically significant. Thus obesity which is an integral component of metabolic syndrome was significantly associated with NAFLD in T2DM individuals in this study. In this study mean total cholesterol was $197.31 \pm 34.10 \mathrm{mg} / \mathrm{dl}$, mean LDL, HDL and TG was $114.18 \pm 35.41 \mathrm{mg} / \mathrm{dl}, 41.85 \pm 2.72 \mathrm{mg} / \mathrm{dl}$ and $186.06 \pm 58.42 \mathrm{mg} / \mathrm{dl}$ respectively. High serum cholesterol was observed in $33.0 \%$ patient, $72.5 \%$ patients had high TG and $8.8 \%$ patients had low HDL and $54.0 \%$ patients had optimal LDL level. In this study hypertriglyceridemia and low HDL were found to be a strong risk factor for NAFLD. In this study no significant association was found between LDL level and occurrence of NAFLD in patients with T2DM ( $\mathrm{p}=0.0405$ ) but higher level of total cholesterol, higher level of TG and low HDL level were statistically significant with higher proportion of NAFLD in T2DM patients $(\mathrm{p}<0.01, \mathrm{p}<0.05, \mathrm{p}<0.05$ respectively. Low HDL level and high TG level were also significantly associated with more severe form of NAFLD $(\mathrm{p}<0.05$ and $\mathrm{p}<0.01$ respectively). $68.2 \%$ patient with NAFLD had high TG level in this study. Thus hypertriglyceridemia and low HDL as a component of metabolic syndrome were significantly associated with increased occurrence and more severe form of NAFLD [37], and found serum total cholesterol $(\mathrm{p}<0.001)$, serum TG $(\mathrm{p}<0.001)$, serum LDL $(\mathrm{p}<0.001)$ and serum HDL $(p=0.004)$ all were significantly associated with higher prevalence of NAFLD in T2DM patients [41], found hypertriglyceridemia and low HDL were significantly associated with NAFLD in T2DM patients $(\mathrm{p}=0.001)$ and $\mathrm{p}<0.0001)$ respectively). The study found no significant relationship between serum LDL and serum HDL level with NAFLD but serum TG level was significantly higher in T2DM patients with NAFLD $(p<0.001)$ [42,43], found no relationship between serum cholesterol and serum triglyceride level and NAFLD in T2DM individuals. [27], found mean triglyceride level was significantly associated with presence of NAFLD ( $\mathrm{p}=0.036)$ but mean cholesterol, HDL and LDL levels did not significantly differ between T2DM patients with or without NAFLD. Found high serum TG and HDL level were significantly associated with presence of fatty change in T2DM patients $(\mathrm{p}=0.011, \mathrm{p}<0.001, \mathrm{p}<0.001$ and $\mathrm{p}<0.001$ respectively) [40, 38]. So our study revealed significant association of NAFLD with hypertriglyceridemia and low HDL level and both were found to be important predictors of fatty changes in liver. In this study mean AST, ALT. AST: ALT, serum albumin and serum bilirubin was $29.47 \pm 5.89 \mathrm{U} / \mathrm{L}, \quad 38.09 \pm 5.77 \mathrm{U} / \mathrm{L}$, $0.077 \pm 0.08, \quad 3.8 \pm 0.22 \mathrm{~g} / \mathrm{dl}$, and $0.45 \pm 0.09 \mathrm{mg} / \mathrm{dl}$ respectively. Levels of liver enzymes like AST, ALT and AST: ALT in T2DM patients with or without NAFLD were within normal range without any statistical significance $(\mathrm{p}=0.94, \mathrm{p}=0.68, \mathrm{p}=0.74$ respectively). It indicated that level of liver enzymes could provide little diagnostic or prognostic value when assessing NAFLD patients and liver enzymes are insensitive markers of NAFLD. The found $30 \%$ patient had abnormal level of AST $(\mathrm{p}=0.039)$ and $22 \%$ had abnormal ALT $(\mathrm{p}=0.214)$ [44]. These results matched with our study. This study was found $86 \%$ prevalence of metabolic syndrome among study population [40]. Patients with T2DM having fatty changes in liver $65 \%$ patient was found to have probability of fibrosis after calculation of BAAT score and $35 \%$ patient with NAFLD had no probable change of fibrosis. Our study provided ultrasonographic proportion of NAFLD in T2DM patients and its significant association with components of metabolic syndrome as well as proportion of metabolic syndrome in patients with T2DM and also in T2DM with NAFLD. Our study also provided a conception of probable fibrosis in patients of T2DM who had NAFLD by calculation of BAAT score. Ultrasonography which is an easily available, cheap tool might be used to determine the presence of fatty changes in liver in T2DM patients as a primary measure in clinical practice. Ultrasonographic presence of fatty liver in T2DM patients along with BAAT score calculation can emphasize clinicians the need to formulate preventive strategies and recommend the high risk individuals to hepatologists for liver biopsy.

\section{CONCLUSION}

NAFLD is a common chronic hepatic disorder globally. T2DM and NAFLD are rapidly increasing reaching level of a pandemic in many countries of the world. Prevalence of NAFLD has increased along with the multiple components of metabolic syndrome. Our study showed that the NAFLD is an integral part of cluster of abnormalities such as DM, dyslipidemia, hypertension and obesity. Prevalence of NAFLD was high among type $2 \mathrm{DM}$ patient. Insulin resistance plays an important role in increasing the severity and progression of the disease. There was strong association of NAFLD with metabolic syndrome, dyslipidemia, increased BMI and central obesity. Age, duration and control of DM are also important contributing factors in occurrence of NAFLD. The results indicate high prevalence $(60.4 \%)$ of fatty liver in T2DM patients in our population and therefore it is necessary to follow them for the consequence of fatty liver. BMI and TG are two predictors of fatty liver in T2DM. 
Ultrasonographic prevalence of fatty liver in T2DM individuals is also an indicator to formulate preventive strategies and periodic assessment of them to avoid complications associated with NAFLD. Finding of NAFLD and its careful management will help us to provide better quality of life in type 2 diabetes. With the growing epidemic of obesity the prevalence and impact of NAFLD continues to increase making NASH potentially the most common cause of advanced liver disease in coming decades. Patients with type $2 \mathrm{DM}$ are at increased risk for developing NAFLD when compared to general population. Patients with established type $2 \mathrm{DM}$ should be screened for NAFLD to avoid diabetes worsening and associated chronic liver disease as well.

\section{REFERENCES}

1. Farrell, G.C., Larter, C.Z. (2006). Nonalcoholic Fatty Liver Disease: from Steatosis to cirrhosis. Hepatology; 43: S00-S112.

2. McCullough, A.J. (2006). Thiazolidinediones for nonalcoholic steatohepatitis-promising but not ready for prime time. $N$ Engl J Med, 355(22): 2361-3.

3. Angulo, P. (2002). Nonalcoholic fatty liver disease. N Engl J Med; 346:1221-1231.

4. Marchesini, G., Marzocchi, R., Agostini, F., Bugianesi, E. (2005). Nonalcoholic fatty liver disease and the metabolic syndrome. Curr Opin Lipidol; 16:421- 427.

5. Feldstein, A.E., Werneburg, N.W., Canbay, A. (2004). Free fatty acids promote hepatic lipotoxicity by stimulating TNF-expression via a lysosomal pathway. Hepatology, 40(1):185-194.

6. Yamaguchi, K., Yang, L., McCall, S. (2007). Inhibiting triglyceride synthesis improves hepatic steatosis but exacerbates liver damage and fibrosis in obese mice with nonalcoholic steatohepatitis. Hepatology; 45(6):1366-1374.

7. Yoon, K.H., Lee, J.H., Kim, J.W., Cho, J.H., Ko, S.H., Zimmet, P., San, H.Y. (2006). Epidemic obesity and type 2 diabetes in Asia. Lancet; 368: 1681-1688.

8. Bedogni, G., Miglioli, L., Masutti, F., Tiribelli, C., [4], G., Bellentani, S. (2005). Prevalence of and risk factors for nonalcoholic fatty liver disease: the dionysos nutrition and liver study. Hepatology; 42(1):44-52.

9. De Oliveira, C.P., de Mello, E.S., Alves, V.A.F., Saviero, S.M., Strauss, E. (2007). Changes in histological criteria lead to different prevalences of nonalcoholic steatohepatitis in severe obesity. Annals of Hepatology; 6(4):255-261.

10. Boza, C., Riquelme, A., Ibanez, L., Duarte, I., Norero, E., Viviani, P. (2005). Predictors of nonalcoholic steatohepatitis (NASH) in obese patients undergoing gastric bypass. Obesity Surgery, 15: 1148-1153.
11. Harnois, F., Msika, S., Sabat'e, J.M. (2006). Prevalence and predictive factors of non-alcoholic steatohepatitis (NASH) in morbidly obese patients undergoing bariatric surgery. Obesity Surgery; 16(2):183-188.

12. Browning, J., Szczepaniak, I., Dobbins, R., Nuremberg, P, Horton, J.D., Cohen, J.C. (2004). Prevalence of Hepatic Steatosis in an Urban Population in the United States: Impact of Ethnicity. Hepatology; 40:1387-95.

13. Browning, J.D. (2006). Statins and hepatic steatosis: perspectives from the Dallas heart study. Hepatology; 44(2):466-471.

14. Amarapurkar, D., Kamani, P., Patel, N., Gupte, P., Kumar, P., Agal, S., Baijal, R., Lata, S., Chaudhury, D., Deshpande, A. (2007). Prevalence of non-alcoholic fatty liver disease: population based study. Annals of hepatology; 6(3): 161-163.

15. Mohan, V., Deepa, R. (2006). Adipocytokines and The expanding «Asian Indian Phenotype. J Assoc Physic Ind; 54: 685-6.

16. Misra, A., Vikram, N.K. (2002). Insulin resistance syndrome (metabolic syndrome) and Asian Indian. Current Science; 83: 1483-96.

17. Medina, J., Fernandez-Salazar, L.I., Garcia-Buey, L., Moreno-Otero, R. (2006). Approach to the pathogenesis and treatment of nonalcoholic steatohepatitis. Diabetes Care, 27: 2057-2066.

18. Jick, S.S., Stender, M., Myers, M.W. (1999). Frequency of liver disease in type 2 diabetic patients treated with oral antidiabetic agents. Diabetes Care, 22:2067-2071.

19. Erbey, J.R., Silberman, C., Lydick, E. (2000). Prevalence of abnormal serum alanine aminotransferase levels in obese patients and patients with type 2 diabetes. Am J Med; 109:588590.

20. Younossi, Z.M., Gramlich, T., Matteoni, C.A., Boparai, N., [2], A.J. (2004). Nonalcoholic fatty liver disease in patients with type 2 diabetes. Clin Gastroenterol Hepatol; 2:262-265.

21. Jimba, S., Nakagami, T., Takahashi, M., Wakamatsu, T., Hirota, Y., Iwamoto, Y., Wasada, T. (2005). Prevalence of nonalcoholic fatty liver disease and its association with impaired glucose metabolism in Japanese adults. Diabet Med; 22:1141-1145.

22. Leite, N.C., Salles, G.F., Araujo, A.L., VillelaNogueira, C.A., Cardoso, C.R. (2009). Prevalence and associated factors of non-alcoholic fatty liver disease in patients with type-2 diabetes mellitus. Liver Int; 29:113-9.

23. Singh, S.P., Nayak, S., Swain, M. (2004). Prevalence of nonalcoholic fatty liver disease in coastal eastern India; a preliminary ultrasonographic survey. Trop Gastroenterol; 25: 76-9.

24. Singh, S.P., Singh, A., Pati, G.K., Misra, B., Misra, D., Kar, S.K., Panigrahi, M.K., Meher, C., 
Agarwal, O., Route, N., Pattnaik, K., Bhuyan, P., Mohapatra, A. (2014). A study of prevalenceof diabetes and prediabetes in patients of nonalcoholic fatty liver disease and the impact of diabetes on liver disease and the impact of diabetes on liver histology in coastal eastern India. Journal of diabetes mellitus; 4: 290-296.

25. Duseja, A., Chawla, Y. (2005). Nonalcoholic fatty liver disease in India How much? How Soon? Trop Gastroenterol; 26: 1-3.

26. Bellentani, S., Marino, M. (2009). Epidemiology and natural history of non-alcoholic fatty liver disease (NAFLD). Ann Hepatol; 8:S4-S8.

27. Merat, S., Yarahmadi, S., Tahaghoghi, S., Alizadeh, Z., Sedighi, N., Mansournia, N., Ghorbani, A., Malekzadeh, R. (2009). Prevalence of fatty liver disease among type 2 diabetes mellitus patients and its relation to insulin resistance. Middle East journal of digestive diseases, 1(2): 74-79.

28. Viswanathan, V., \& Kumpatla, S. (2010). Association of nonalcoholic fatty liver disease with diabetic microvascular and macrovascular complications in south Indian diabetic subjects. Int J Diabet Develop Countr; 30(4): 208.

29. Osawa, H., Mori, Y. (1996). Sonographic diagnosis of fatty liver using a histogram technique that compares liver and renal cortical echo amplitudes. Journal of clinical ultrasound, 24(1): 25-96.

30. Saverymuttu, S.H., Joseph, A.E., Maxwell, J.D. (1986). Ultrasound scanning in the detection of hepatic fibrosis and steatosis. British medical Journal, 292(6512): 13.

31. Contos, M.J., Sanyal, A.J. (2002). The clinicopathologic spectrum and management of non-alcoholic fatty liver disease. Advances in anatomy and physiology; 9: 37-51.

32. Lonardo, A., Bellini, M., Tartoni, P., Tondelli, E. (1997). The bright liver syndrome: prevalence and determinants of a bright liver echopattern. Ital $J$ gastroenterol hepatol; 29: 351-356.

33. Tominaga, K., Kurata, J.H., Chen, Y.K. (1995). Prevalence of fatty liver in Japanese Children and relationship to obesity: An epidemiological ultrasonographic survey. Dig Dis Sci; 40: 20022009.

34. Cho, C.S., Curran, S., Schwartz, L.H., Kooby, D.A., Klimstra, D.S., Shia, J., Dematteo, R.P. (2008). Preoperative radiographic assessment of hepatic steatosis with histologic correlation.
Journal of the American College of Surgeons; 206(3): 480-488.

35. Sibia, R.S., Dhoot, S., Sibia, P. Murarka, S., Bhardwaj, H., Aggarwal, A.D. (2016). Prevalence of nonalcoholic fatty liver disease in patients with type 2 diabtes and its correlation with coronary risk factors. National journal of laboratory medicine, 5(4): 1011-1013.

36. Luxmi, S., Sattar, R.A., Ara, J. (2008). Association of nonalcoholic fatty liver with type 2 diabetes mellitus. JLUMHS; 188-193.

37. Sharavanan, T.K.V., Premalatha, E. (2015). Prevalence of non-alcoholic fatty liver disease in type 2 diabetes mellitus patients in a rural health care hospital. Sch. J. App. Med. Sci; 3(5A): 1834-7.

38. Rao, S.V., Sikariya, K.K. (2016). Prevalence and risk factors of nonalcoholic fatty liver disease in type 2 diabetes mellitus in a tertiary care centre in western India. IOSR journal of dental and medical sciences; 15(2): 01-07.

39. Bakalov, D., Boyanov, M., Sheinkova, G., Vezenkova, L., Prodanova, G., Christov, V., 2010. Non-alcoholic fatty liver disease (NAFLD) in men with type 2 diabetes. J Clin Med, 3(3): 31-35.

40. Targher, G., Bertolini, L., Padovani, R. Rodella, S., Tessari, R., Zenari, L., Padovani, R., Day, C., Arcaro, G., 2007. Prevalence of nonalcoholic fatty liver disease and its association with cardiovascular disease among type 2 diabetic patients. Diabetic care; 30(5): 1212-1218.

41. Somalwar, A.M., Raut, A.D. (2014). Study of association of now alcoholic fatty liver disease (NAFLD) with micro and macrovascular complications of type 2 diabetes mellitus (T2DM). Int J Res Med Sci, 2(2): 493-497.

42. Shahbazian, H.B., Hashemi, S.J., Latifi, S.M., Lashkarara, G., Attar, G.A. (2011). Prevalence of fatty liver disease nad its risk factors in type 2 diabetic patients. Iranian Journal of Diabetes and obesity; 3(2): 83-87.

43. Shinde, P.A. (2016). Prevalence of Nonalcoholic fatty liver disease (NAFLD) and nonalcoholic steatohepatitis in type 2 diabetes mellitus-A prospective study. International archives of biomedical and clinical research, 2(4): 49-51.

44. Jali, M.V., Kambar, S., Jali, S.M., Hiremath, M.B. (2015). Prevalence of nonalcoholic fatty liver disease among type-2 diabetes mellitus patients-A cross-sectional hospital based study. Al Ameen $J$ med Sci, 8(1): 50-54. 